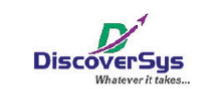

Published by DiscoverSys

\section{Relationship between anxiety and sleep quality in patients attending Kecamatan Penjaringan Public Health Center, North Jakarta}

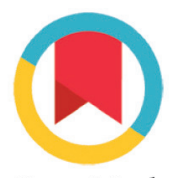

CrossMark
Micheline Chang, ${ }^{1 *}$ Surilena Hasan, ${ }^{2}$ Erfen Gustiawan Suwangto, ${ }^{3}$ Nelly Tina Widjaja ${ }^{4}$
${ }^{1}$ Faculty of Medicine and Health Sciences, Atma Jaya Catholic University of Indonesia ${ }^{2}$ Department of Psychiatry and Behavioural Sciences, Faculty of Medicine and Health Sciences, Atma Jaya Catholic University of Indonesia

${ }^{3}$ Department of Ethics, Faculty of Medicine and Health Sciences, Atma Jaya Catholic University of Indonesia

${ }^{4}$ Department of Public Health and Nutrition, Faculty of Medicine and Health Sciences, Atma Jaya Catholic University of Indonesia

*Correspondence to:

Micheline Chang; Faculty of Medicine and Health Sciences, Atma Jaya Catholic University of Indonesia;

changmicheline@gmail.com

\section{INTRODUCTION}

Anxiety can be considered as a human's normal emotion, however, if the anxiety becomes chronic or severe or begin to impair daytime functioning, it is classified as an illness or disorder. ${ }^{1}$ There has been a rapid rise in the prevalence of anxiety over the last decade, globally. The World Health Organization $(\mathrm{WHO})^{2}$ in 2017 estimated 264 million of people in the world living with anxiety disorders, $23 \%$ of whom were living in Southeast Asia. In Indonesia, anxiety disorders affect about 3,3\% (8 million) of the population, which rank second in Southeast Asia. ${ }^{2}$ Data from Institute for Health Metrics and Evaluation (IHME) ${ }^{3}$ showed that the prevalence of anxiety disorders in Indonesia was twice higher among female $(4.12 \%$ compared to $2.42 \%$ among male). Based on age groups, adults aged 50-69 years old $(4.53 \%)$ have the highest prevalence of anxiety disorder, followed by the elderly aged 70 years and older (4.31\%), $15-49$ years old (3.8\%), 5-14 years old of them were female, $56.2 \%$ with basic education, $54.8 \%$ were unemployed and $61.1 \%$ with low-income level. As high as $26.3 \%$ of the respondents were fallen into anxiety classification, including $19.4 \%$ mild anxiety, $5.5 \%$ moderate anxiety and $1.4 \%$ severe anxiety; while $53.5 \%$ of them reported poor sleep quality. Bivariate analysis showed a significant relationship between anxiety and sleep quality in patients attending Kecamatan Penjaringan PHC, North Jakarta $(P<0.001)$. Patients with anxiety were 7.8 times $(\mathrm{OR}=7.819,95 \% \mathrm{Cl}: 4.462-13.703)$ more likely to experience poor sleep quality than those without anxiety.

Conclusion: There is a significant relationship between anxiety and sleep quality in patients attending Kecamatan Penjaringan PHC, North Jakarta. Detection of anxiety disorders and sleep quality should be considered as one essential part of patients' care at PHC.

Keywords: Anxiety, sleep, primary health care

Cite this Article: Chang, M., Hasan, S., Suwangto, E.G., Widjaja, N.T.2020. Relationship between anxiety and sleep quality in patients attending Kecamatan Penjaringan Public Health Center, North Jakarta. Public Health and Preventive Medicine Archive 8(1): 41-46. DOI:10.15562/phpma.v8i1.232

$(2.13 \%)$ and children under age $5(0.09 \%){ }^{3}$

Anxiety disorder does not cause death directly but may lead to disability. Recent findings showed that anxiety disorder is the sixth leading cause of disability both in high and low-middle income countries. ${ }^{4}$ Anxiety disorder often manifest as muscle tensions, the anticipation of future threats, vigilance and avoidant behaviors in preparation for immediate or future dangers. ${ }^{1}$ It is suggested that anxiety disorder is commonly accompanied by sleep problems, especially in people with a generalized anxiety disorder (GAD) and panic disorder (PD). ${ }^{4}$ People with GAD tends to suffer a full day-long episode of anxiety, while PD has a high level of anxiety sensitivity, which may cause an increase of attention, fearfulness and excessive arousal in individual. ${ }^{4,5}$ Both mechanisms may result in lack of sleep and cause sleep disruptions.

Sleep problems can be caused by physical or psychological illness and may have affected one's

Open access: https:/phpmajournalorg/index.php/phpma/issue/view/17 
health condition and sleep quality. Poor sleep quality can furtherly impact daily activities, productivity, and quality of life, which strongly associated with an individual's social and economic impact. ${ }^{6}$ Stranges, et al. ${ }^{7}$ study showed $16.6 \%$ (150 million) people living in developing countries aged 50 years and older have poor sleep quality. In Indonesia, 4.6\% female and $3.9 \%$ male were found with poor sleep quality, meanwhile, as high as $72.8 \%$ elderly (aged 60 years and above) with poor sleep quality was found in primary health care. ${ }^{7,8}$ High prevalence of poor sleep quality (63.5\%) was also reported among anxiety patients with chronic disease who visited public health center. ${ }^{9}$

Primary health care is one of the first-level health care services and non-specialist practice that focuses on individual, including outpatient and inpatient care..$^{10}$ Primary health care such as public health centers (PHCs) are widely available in the community. PHC patients usually come and present with physical problems, while mental disorders such as anxiety disorders are frequently undetected, misdiagnosed or late diagnosed. In previous studies, it has been reported that there is a high prevalence of anxiety, depression, and psychosomatic in patients visiting PHC ${ }^{11}$ Similarly, sleep problems are commonly found in patients in primary health care, but often goes unaddressed and untreated. ${ }^{12}$

Inadequate detection and treatment of anxiety in patients may worsen the primary illness and worsen the prognosis. ${ }^{13}$ Recent findings showed there is a strong association between anxiety, depression, and sleep quality regarding to suicidal ideation and increases the risk of suicide. ${ }^{14}$ Most studies on anxiety and sleep quality have been conducted in particular patient groups, especially among anxiety disorder patients, which may not fully represent patients who visited PHCs.

Therefore, understanding the association between anxiety and sleep quality in primary care patients is essential to improve quality of care among PHC patients. This study aims to determine the relationship between anxiety and sleep quality in patients attending Kecamatan Penjaringan PHC, North Jakarta.

\section{METHODS}

A cross-sectional study was carried out among outpatients attending Kecamatan Penjaringan PHC (Puskesmas Kecamatan Penjaringan), North Jakarta, from August to October 2019. Kecamatan Penjaringan PHC is one of the primary health centers in Penjaringan and has been a major service for primary care settings in the population. The inclusion criteria for the subjects were outpatients attending the health care service of Kecamatan Penjaringan PHC and adults aged 17 years and older. Those who refused to participate, did not sign the informed consent, did not complete the questionnaires, unable to communicate properly, diagnosed with mental disorders and currently undergoing therapies were excluded from the study. Respondents whom previously had been diagnosed with mental disorders such as anxiety disorder, depression and others, and are currently undergoing therapies have been excluded from the study since the purpose of the study is to determine anxiety in patients attending primary health center, while medical treatments regarding the psychological symptoms may improve the respondent's conditions and affect the sleep quality.

The sampling technique used in this study was consecutive sampling. Consecutive sampling is a sampling method where subjects are taken sequentially and have met the inclusion criteria. The sample size was calculated using the crosssectional formula with a level of confidence $95 \%$, power $80 \%$, precision $10 \%$ and due to the unknown proportion of anxiety in the population, we assumed the proportion by $50 \%$. A minimum sample of 385 patients were invited to participate.

The study was performed by the main researcher and several trained research assistants. A brief introduction of the study was explained to the respondents, and a signed informed consent was obtained from all respondents before the study. There were 4 instruments used in this study, including demographic, drug consumption questionnaire, Zung Self-rating Anxiety Scale (SAS), and Pittsburgh Sleep Quality Index (PSQI). The demographic questionnaire identifies age, gender, education level, employment, and income level in this study. The drug consumption questionnaire identifies and excludes the consumption of psychiatric medication. Zung Self-rating Anxiety Scale (SAS) determines the presence of anxiety and measure the anxiety levels for the past one week prior to this study. SAS consists of 20 items, each item was scored 1 (none, or a little of the time) to 4 (most, or all of the time). ${ }^{15}$ The total SAS score ranging from $20-80$ is considered as the raw score, which will be converted into index score by dividing the sum of raw score by 80 and multiplying by 100 . Index score will be obtained ranging from 25-100. A conversion table of raw score into index score is also available in Zung's study. ${ }^{16}$ Index score of 45 and above was set as the cut-off point for anxiety. ${ }^{15}$ SAS was created and validated in hospital setting by William K. Zung, while the Indonesian version of SAS was validated by Setyowati, et al. ${ }^{17}$ The Pittsburgh Sleep Quality Index (PSQI) identifies 
subjective sleep quality retrospectively over the last one month prior to this study. PSQI consists of 19 items to measure 7 domains of sleep quality, each item was scored from 0 to 3 . A global sleep quality was obtained ranging from $0-21$. Poor sleep quality was determined with a cut-off point of 5 and above. PSQI was developed and validated in psychiatric center by Daniel J. Buysse and validated in Indonesia by Alim, et al. ${ }^{18,19}$ All of the instruments used in this study are self-administered questionnaires and were assisted with interviews when necessary.

Data analysis were including univariate and bivariate analysis using SPSS Statistics 25 for Windows. Chi-square Test was used to determine the relationship between anxiety and sleep quality. The study was approved by the Ethics Committee of Faculty of Medicine and Health Sciences, Atma Jaya Catholic University of Indonesia (No: 05/03/KEPFKUAJ/2019) on March $4^{\text {th }}, 2019$.

Table 1. Characteristics of respondents

\begin{tabular}{|c|c|c|c|}
\hline Variables & & $\mathbf{n}$ & $\%$ \\
\hline \multicolumn{4}{|c|}{ Age (years) } \\
\hline & $17-25$ & 33 & 7.6 \\
\hline & $26-35$ & 67 & 15.4 \\
\hline & $36-45$ & 81 & 18.7 \\
\hline & $46-55$ & 133 & $30.6^{*}$ \\
\hline & $56-65$ & 81 & 19.4 \\
\hline & $>65$ & 36 & 8.3 \\
\hline \multicolumn{4}{|l|}{ Gender } \\
\hline & Male & 120 & 27.6 \\
\hline & Female & 314 & $72.4^{*}$ \\
\hline \multicolumn{4}{|l|}{ Education } \\
\hline & Uneducated & 26 & 6.0 \\
\hline & Primary education (SD-SMP/MTs) & 244 & $56.2^{*}$ \\
\hline & Secondary education (SMA/SMK) & 130 & 30.0 \\
\hline & Tertiary education (D3/S1) & 34 & 7.8 \\
\hline \multicolumn{4}{|c|}{ Employment } \\
\hline & Unemployed & 235 & $54.1^{*}$ \\
\hline & Employed & 199 & 45.9 \\
\hline \multicolumn{4}{|c|}{ Income Level } \\
\hline & Low-income level & 265 & $61.1^{*}$ \\
\hline & High-income level & 169 & 38.9 \\
\hline \multicolumn{4}{|l|}{ Anxiety } \\
\hline & & 320 & 73.7 \\
\hline & Yes & 114 & 26.3 \\
\hline & - $\quad$ Mild & 84 & $19.4^{*}$ \\
\hline & - Moderate & 24 & 5.5 \\
\hline & - $\quad$ Severe & 6 & 1.4 \\
\hline \multicolumn{4}{|c|}{ Sleep Quality } \\
\hline & Good & 202 & 46.5 \\
\hline & Poor & 232 & $53.5^{*}$ \\
\hline
\end{tabular}

${ }^{\star}$ Highest proportion

\section{RESULTS}

This study invited 446 respondents, 12 respondents were excluded according to the exclusion criteria, and a total of 434 respondents participated and completed the questionnaires.

Table 1 shows the characteristics of respondents by age, gender, education, employment and income level. The respondents age ranged from 17 to 81 years old, with an average of 47.1 years old, $72.4 \%$ were female, $56.2 \%$ with primary education, $54.8 \%$ were unemployed, and $61.1 \%$ reported with lowincome level. There were $26.3 \%$ respondents identified with anxiety. Mild anxiety was the most frequent-as high as $19.4 \%$, followed by moderate anxiety (5.5\%) and severe anxiety (1.4\%). Poor sleep quality $(53.5 \%)$ was more prevalent than good sleep quality $(46.5 \%)$.

Table 2 illustrates the distribution of respondents by anxiety and sleep quality. Anxiety was identified predominantly in respondents aged 46-55 years old $(33.3 \%)$, female $(80.7 \%)$, with basic education (70.2\%), unemployed (54.4\%) and with lowincome level (64.9\%). Similarly, poor sleep quality is commonly seen in respondents aged $46-55$ years old $(33.6 \%)$, female $(73.3 \%)$, with basic education (56.9\%), unemployed (53.9\%), and with lowincome level (62.1\%).

Table 3 summarized the relationship between anxiety and sleep quality in patients attending Kecamatan Penjaringan PHC. Bivariate analysis with Chi-square test showed a significant relationship $(\mathrm{p}<0.001)$ between anxiety and sleep quality of respondents attending this PHC with odds ratio $(\mathrm{OR})=7.819$.

\section{DISCUSSION}

The results of this study showed, of 434 respondents, most were female, with basic education, unemployed and with low-income level. This result was similar to a study conducted by Hidayat, et al. $(2010)^{11}$ involving 1052 patients who attended Kecamatan Grogol Petamburan PHC, West Jakarta; in which the majority of patients who attended public health center were female (62\%) and with basic education (34.2\%). The respondent's characteristics of this study are also similar to Sitorus and Fitrikasari's $(2016)^{20}$ study among 52 Halmahera Semarang PHC patients, wherein the vast majority of patients attending public health center were aged 40 years and older (30.8\%) and $23.1 \%$ were unemployed.

Interestingly, high prevalence of anxiety was detected in this study $(26.3 \%)$, in which mild anxiety was the most common (19.4\%), followed by moderate anxiety (5.5\%) and severe anxiety (1.4\%). It is well known that different instruments used 
Table 2. Distribution of respondents by anxiety and sleep quality

\begin{tabular}{|c|c|c|c|c|c|}
\hline \multirow{2}{*}{ Variables } & & \multicolumn{2}{|c|}{ Anxiety } & \multicolumn{2}{|c|}{ Sleep quality } \\
\hline & & No & Yes & Good & Poor \\
\hline \multicolumn{6}{|l|}{ Age (years) } \\
\hline & $17-25$ & $32(10 \%)$ & $8(7.0 \%)$ & $20(9.9 \%)$ & $20(8.6 \%)$ \\
\hline & $26-35$ & $47(14.7 \%)$ & $18(15.8 \%)$ & $31(15.3 \%)$ & $34(14.7 \%)$ \\
\hline & $36-45$ & $65(20.3 \%)$ & $20(17.5 \%)$ & $39(19.3 \%)$ & $46(19.8 \%)$ \\
\hline & $46-55$ & $91(28.4 \%)$ & $38(33.3 \%)^{*}$ & $51(25.2 \%)$ & $78(33.6 \%)^{*}$ \\
\hline & $56-65$ & $58(18.1 \%)$ & $23(20.2 \%)$ & $42(20.8 \%)$ & $39(16.8 \%)$ \\
\hline & $>65$ & $27(8.4 \%)$ & $7(6.1 \%)$ & $19(9.4 \%)$ & $15(6.5 \%)$ \\
\hline \multicolumn{6}{|l|}{ Gender } \\
\hline & Male & $98(30.6 \%)$ & $22(19.3 \%)$ & $58(28.7 \%)$ & $62(26.7 \%)$ \\
\hline & Female & $222(69.4 \%)$ & $92(80.7 \%)^{*}$ & $144(71.3 \%)$ & $170(73.3 \%)^{\star}$ \\
\hline \multicolumn{6}{|l|}{ Education } \\
\hline & Uneducated & $19(5.9 \%)$ & $7(6.1 \%)$ & $10(5.0 \%)$ & $16(6.9 \%)$ \\
\hline & Primary education (SD-SMP/MTs) & $164(51.2 \%)$ & $80(70.2 \%)^{*}$ & $112(55.4 \%)$ & $132(56.9 \%)^{*}$ \\
\hline & Secondary education (SMA/SMK) & $106(33.1 \%)$ & $24(21.1 \%)$ & $58(28.7 \%)$ & $72(31.0 \%)$ \\
\hline & Tertiary education (D3/S1) & $31(9.7 \%)$ & $3(2.6 \%)$ & $22(10.9 \%)$ & $12(5.2 \%)$ \\
\hline \multicolumn{6}{|c|}{ Employment } \\
\hline & Unemployed & $173(54.1 \%)$ & $62(54.4 \%)^{*}$ & $110(54.5 \%)$ & $125(53.9 \%)^{*}$ \\
\hline & Employed & $147(45.9 \%)$ & $52(45.6 \%)$ & $92(45.5 \%)$ & $107(46.1 \%)$ \\
\hline \multicolumn{6}{|c|}{ Income Level } \\
\hline & Low-income level & $191(59.7 \%)$ & $74(64.9 \%)^{*}$ & $121(59.9 \%)$ & $144(62.1 \%)^{*}$ \\
\hline & High-income level & $129(40.3 \%)$ & $40(35.1 \%)$ & $81(40.1 \%)$ & $88(37.9 \%)$ \\
\hline
\end{tabular}

${ }^{\star}$ Highest proportion

Table 3. The relationship between anxiety and sleep quality in patients attending Penjaringan Public Health Center, North Jakarta

\begin{tabular}{|c|c|c|c|c|c|}
\hline & & \multicolumn{2}{|c|}{ Sleep quality } & \multirow[b]{2}{*}{$\mathbf{p}$} & \multirow[b]{2}{*}{ OR } \\
\hline & & $\begin{array}{l}\text { Good } \\
\text { n (\%) }\end{array}$ & $\begin{array}{l}\text { Poor } \\
\text { n (\%) }\end{array}$ & & \\
\hline \multirow[t]{2}{*}{ Anxiety } & No & $185(57.8 \%)$ & $135(42.2 \%)$ & \multirow{2}{*}{$<0.001$} & 7.819 \\
\hline & Yes & $17(14.9 \%)$ & 97 (85.1\%) & & $\begin{array}{l}13.703 \\
13.402^{-}\end{array}$ \\
\hline
\end{tabular}

to measure anxiety may affect the prevalence of anxiety captured in a study population. An almost similar prevalence was found in Bunevicius, et al's $(2014)^{13}$ study that was conducted to patients who attended four primary health cares in Lithuania. There were 998 patients participated in the study and $21 \%$ patients reported with anxiety disorder. GAD has the highest prevalence (18\%), followed by social phobia (3\%), panic disorder $(3 \%)$, and PTSD (2\%). The study used Mini International Neuropsychiatric Interview (MINI) to detect anxiety and other psychiatric diagnoses. A greater prevalence of anxiety was found using Generalized Anxiety Disorder-7 (GAD-7) in Alkhathami, et al.s (2017) study. ${ }^{9}$ The study was conducted in 368 people who attended primary health care in Saudi Arabia with diabetes mellitus and/or hypertension.
Approximately $38.4 \%$ of the patients were reported with anxiety, including $25.1 \%$ patients with mild anxiety, $8.8 \%$ patients with moderate anxiety and $4.4 \%$ patients with severe anxiety. The most probable reason why the result of this study is different to Alkhathami, et al's study (2017) is due to cultural differences that may impact the prevalence of anxiety in a population. Moreover, anxiety disorder was detected with a higher prevalence in Middle East countries than Southeast Asian countries. ${ }^{3}$

Another study by Sitorus and Fitrikasari $(2016)^{20}$ shows most outpatients who attended Halmahera Semarang PHC were with mild anxiety (80.8\%) and moderate anxiety (19.2\%). The study used Beck Anxiety Inventory (BAI) to detect and measure anxiety in outpatients of the PHC. The study of Anggraini, et al. (2013) ${ }^{21}$ among 30 asthma patients from a Semarang community stated $26.7 \%$ patients were with mild to moderate anxiety, while $13.3 \%$ patients were with severe anxiety.

Most of our study respondents have a poor sleep quality (53.5\%). A lower prevalence was found in a study conducted by Kang, et al. (2013) ${ }^{12}$ among 129 South Korean couples aged 30 years or older in primary health care, in which $38 \%$ patients were identified with poor sleep quality. An almost similar prevalence was found in Anggraini, et al's $(2013)^{21}$ study, among asthma patients in Semarang community center, wherein $56.7 \%$ 
of them was detected with poor sleep quality. A higher prevalence of poor sleep quality was found in Lugito, et al.s $(2018)^{8}$ study that was conducted among 92 geriatric patients in a general hospital setting, with $72.8 \%$ patients were reported with poor sleep quality. Evidently, there were several different factors that affect one's sleep quality in the past study, such as depression, spouse's poor sleep quality and the comorbidity of chronic disease. ${ }^{8,12,21}$ Patients with chronic diseases generally experience poor sleep quality. Pain and discomfort are often felt during sleep and may lead to a decrease of sleep latency and waking up during sleep. Poor sleep quality in patients with chronic disease needs to be addressed since it may worsen the illnesses and increase the risk of death. ${ }^{6}$

This study found a significant relationship between anxiety and sleep quality among respondents. The result of this study was consistent with Hacimusalar and Karaaslan's $(2019)^{4}$ study that was conducted to GAD and panic disorder patients in a psychiatric clinic. GAD has the strongest relationship with poor sleep quality. GAD in patients with insomnia will generally have impact in feeling dissatisfied with the quantity and quality of sleep subjectively and objectively, could not feel refreshed and energized after awake. ${ }^{22,23}$ Moreover, sleep quality does not improve in GAD patients that are in remission. ${ }^{4}$ Patients with panic disorder tend to have unexpected panic attacks during sleep and may increase sleep latency, decrease sleep duration, increase daytime sleepiness and sleep disturbances. Panic disorder is also commonly comorbid with depression. ${ }^{4,23}$ Social phobia has also a strong relationship with sleep quality, in which patients with social phobias tend to experience increase in sleep latency, sleep problems, and daytime dysfunction. ${ }^{22}$

Baker, et $a .^{5}$ stated anxiety patients often experience anxiety before going to sleep, anxiety and fear generates a fight or flight response that can interfere the sleep onset. Increased levels of serotonin release induces anxiety, stress, and fear, so that the body will respond by waking up from sleep. These conditions may affect one's sleep quality. Anxiety disorder patients with poor sleep quality often experience a decrease in quality of life, increased risk of disability, health risks and risk of death. ${ }^{22}$ Moreover, there has been a strong association between anxiety, depression, and sleep quality with suicidal ideation. ${ }^{13,14}$ Anxiety disorders patients with poor sleep quality are generally found with other mental illness comorbidities that can affect one's quality of life. One third of anxiety disorders patients with poor sleep quality have experienced functional impairment due to emotional problems or drug use at least 1 day during the past. ${ }^{22}$
Zung Self-rating Anxiety Scale (SAS) was used in this study and estimated $26.3 \%$ respondents with anxiety. SAS has a sensitivity of $89 \%$ and specificity of $69 \%$, these percentages indicate that this questionnaire is well used at predicting anxiety. A study conducted by Dunstan, et al. ${ }^{15}$ reported that false interpretation results were found in several studies, in which the questionnaire's cut off limit was often used on the raw score without being converted to index score on Zung's, thus causing the possibility of misinterpretation and false positive results. Misinterpretation of the results can reduce the sensitivity of the questionnaire to $31 \%$. Hence, this can be prevented by further studies of the instruments before data collection to gain a better understanding of the instruments.

There were some limitations in this study, including some questions were difficult to understand by respondents with basic education (SD\&SMP) and several respondents also had difficulties in reading and writing.

\section{CONCLUSION}

This study reports the relationship between anxiety and sleep quality in patients attending Kecamatan Penjaringan PHC, North Jakarta. There were 26.3\% respondents with anxiety, including $19.4 \%$ mild anxiety, $5.5 \%$ moderate anxiety, and $1.4 \%$ severe anxiety. Meanwhile, there were $53.5 \%$ respondents with poor sleep quality and $85.1 \%$ respondents with anxiety also had poor sleep quality. There is a significant relationship between anxiety and sleep quality in patients attending Kecamatan Penjaringan PHC, North Jakarta. Respondents with anxiety had a 7.8 times greater risk of experiencing poor sleep quality than those without anxiety. Anxiety disorders may worsen the illness and prognosis of patients seeking care at PHC. Detection of anxiety disorders and sleep quality should be considered as one essential part of patients'care at PHC.

\section{ACKNOWLEDGEMENTS}

We would like to thank One-Gate Integrated Service (Unit Pusat Pelayanan Terpadu Satu Pintu/PTSP) of North Jakarta, North Jakarta District Health Office (Suku Dinas Kesehatan), and Kecamatan Penjaringan Public Health Center (Puskesmas Kecamatan Penjaringan) for permitting to conduct this study. We would also like to appreciate all respondents who participated in this study.

\section{AUTHOR CONTRIBUTION}

$\mathrm{MC}, \mathrm{SH}$ and ES designed and conceptualized the study. MC and ES collected and analyzed the data. $\mathrm{MC}$ and SH wrote the first draft of manuscript. MC, 
$\mathrm{SH}$, and ES edited the manuscript. NW was involved in designing the study, supported the data analysis and provided feedback to the manuscript. SH, ES and NW critcially reviewed the study proposal.

\section{CONFLICT OF INTEREST}

No conflicts of interest declared by the authors.

\section{FUNDING}

The study was self-funded by the research team.

\section{REFERENCES}

1. American Psychiatric Association. Diagnostic and Statistical Manual of Mental Disorders (DSM-V). 5th ed. Arlington, VA: American Psychiatric Publishing; 2013. p. 189.

2. World Health Organization. Depression and other common mental disorders: global health estimates. Geneva: World Health Organization; 2017. p. 8, 20.

3. Ritchie H, Roser M. Mental health: Our world data. 2018 [cited 2020 January 5]. Available from: https:// ourworldindata.org/mental-health.

4. Hacimusalar Y, Karaaslan O. Assessment of sleep quality of patients with panic disorder and generalized anxiety disorder during remission: a case-control study. Arch Clin Psychiatry São Paulo. 2020;47(1):19-24.

5. Baker AW, Keshaviah A, Goetter EM, Bui E, Swee M, Rosencrans PL, et al. Examining the role of anxiety sensitivity in sleep dysfunction across anxiety disorders. Behav Sleep Med. 2017;15(3):216-227.

6. Barros MB de A, Lima MG, Ceolim MF, Zancanella E, Cardoso TAM de O. Quality of sleep, health and well-being in a population-based study. Rev Saúde Pública. 2019;53:82.

7. Stranges S, Tigbe W, Gómez-Olivé FX, Thorogood M, Kandala N-B. Sleep problems: An emerging global epidemic? Findings from the INDEPTH WHO-SAGE Study among more than 40,000 older adults from 8 countries across Africa and Asia. Sleep. 2012;35(8):11731181 .

8. Lugito NPH, Yanto TA, Kurniawan A, Wijaya I, Tjiang MM, Setiadinata R, et al. Poor sleep quality of hospitalized geriatric patients in general hospital in Karawaci, Tangerang, Banten Province, Indonesia. Medicinus. 2018;6(1).

9. AlKhathami $\mathrm{AD}$, Alamin MA, Alqahtani AM, Alsaeed WY, AlKhathami MA, Al-Dhafeeri AH. Depression and anxiety among hypertensive and diabetic primary health care patients: Could patients' perception of their diseases control be used as a screening tool? Saudi Med J. 2017;38(6):621-628.

10. Ministry of Health of Indonesia. Peraturan Menteri Kesehatan Republik Indonesia Nomor 71 Tahun 2013 Tentang Pelayanan Kesehatan pada Jaminan Kesehatan Nasional. [Regulation of the Ministry of Health of the Republic of Indonesia Number 71 of 2013 About Health Care Services on National Health Insurance] Jakarta: Ministry of Health of Indonesia. 2013.
11. Hidayat D, Ingkiriwang E, Andri AE, Widya RS, Susanto DH. Penggunaan metode dua menit (M2M) dalam menentukan prevalensi gangguan jiwa di pelayanan primer. [The usage of Two Minutes Method (M2M) to determine mental disorder prevalence in primary care]. Maj Kedokt Indon. 2010;60(10):448-454.

12. Kang J-M, Lee JA, Jang J-W, Kim YS, Sunwoo S. Factors associated with poor sleep quality in primary care. Korean $J$ Fam Med. 2013;34(2):107-114.

13. Bunevicius R, Liaugaudaite V, Peceliuniene J, Raskauskiene $\mathrm{N}$, Bunevicius A, Mickuviene N. Factors affecting the presence of depression, anxiety disorders, and suicidal ideation in patients attending primary health care service in Lithuania. Scand J Prim Health Care. 2014;32(1):24-29.

14. Wigg CMD, Filgueiras A, Gomes $\mathrm{M}$ da $\mathrm{M}$, Wigg CMD, Filgueiras A, Gomes $\mathrm{M}$ da $\mathrm{M}$. The relationship between sleep quality, depression, and anxiety in patients with epilepsy and suicidal ideation. Arq Neuropsiquiatr. 2014;72(5):344-348.

15. Dunstan DA, Scott N, Todd AK. Screening for anxiety and depression: reassessing the utility of the Zung scales. $B M C$ Psychiatry. 2017;17(1):329.

16. Zung WWK. A rating instrument for anxiety disorders. Psychosomatics. 1971;12(6):371-379.

17. Setyowati A, Chung MH, Yusuf A. Development of selfreport assessment tool for anxiety among adolescents: Indonesian version of the zung self-rating anxiety scale. $J$ Public Health Afr. 2019;10(S1):1172.

18. Buysse DJ, Reynolds CF, Monk TH, Berman SR, Kupfer DJ. The Pittsburgh sleep quality index: A new instrument for psychiatric practice and research. Psychiatry Res. 1989;28(2):193-213.

19. Alim IZ, Elvira SD, Amir N, Noorhana. Uji validitas dan reabilitas instrumen Pittsburgh Sleep Quality Index versi Bahasa Indonesia [Test validity and reliability of the instrument Pittsburgh Sleep Quality Index Indonesia Language version] Jakarta: Fakultas Kedokteran Universitas Indonesia; 2015.

20. Sitorus PE, Fitrikasari A. Gambaran tingkat kecemasan dan hubungannya dengan berbagai faktor pada pasien rawat jalan puskesmas (Studi deskriptif analitik di Puskesmas Halmahera Semarang) [Description of anxiety level and the relationships with different factors in outpatients of public health center (An analytical descriptive study at Halmahera Public Health Center, Semarang)]. J Kedokt Diponegoro. 2016;5(4):1451-1460.

21. Anggraini MT, Rihadini, Tsaqofah F. Tingkat kecemasan mempengaruhi kualitas tidur pada penderita asma bronkial usia lanjut [Anxiety levels affecting of sleep in asthma bronchial elderly patients]. J Kedokt Muhammadiyah. 2014;3(2).

22. Ramsawh HJ, Stein MB, Belik S-L, Jacobi F, Sareen J. Relationship of anxiety disorders, sleep quality, and functional impairment in a community sample. J Psychiatr Res. 2009;43(10):926-933.

23. Simon EK, Berki ZHK, Gettys GC, Vedak C. Sleep problems and disorders in patients with anxiety disorders. Psychiatr Ann. 2016;46:396-400.



This work is licensed under a Creative Commons Attribution 